\title{
AKTIVITAS ANTIBAKTERI AMOKSISILIN TERHADAP BAKTERI GRAM POSITIF DAN BAKTERI GRAM NEGATIF
}

\section{AMOXICIILLIN ANTIBACTERIAL ACTIVITIES ON POSITIVE GRAM BACTERIA AND NEGATIVE GRAM BACTERIA}

\author{
Surah Maida*, Kinanti Ayu Puji Lestari \\ Program Studi DIII Farmasi, Akademi Farmasi Surabaya \\ *Email: fahida1619@gmail.com
}

Diterima: 25 Januari 2019. Disetujui: 24 Juli 2019. Dipublikasikan: 30 September 2019

\begin{abstract}
Abstrak: Amoksisilin merupakan antibiotik yang sering digunakan dalam berbagai pengobatan dan efektif membunuh bakteri Gram positif dan Gram negatif. Penelitian ini bertujuan untuk mengetahui aktivitas antibakteri amoksisilin terhadap bakteri Gram positif (Bacillus subtilis, Staphylococcus aureus) dan bakteri Gram negatif (Escherichia coli, Pseudomonas aeruginosa). Metode penelitian ini meliputi pembuatan konsentrasi antibiotik (10 ppm, 15 ppm, 20 ppm, 25 ppm, 30 ppm); pengujian antibakteri dengan metode kertas cakram serta pengkuran zona hambat yang terbentuk. Didapatkan data bahwa rata-rata zona hambat yang terbentuk dari keempat bakteri tersebut sebesar 0,03 - 0,44 mm. Pada konsentrasi $30 \mathrm{ppm}$, menunjukkan bahwa bakteri Staphylococcus aureus dan Escherichia coli menghasilkan zona hambat yang terluas yaitu sebesar 0,38 mm dan 0,44 mm. Disimpulkan bahwa sensitivitas keempat bakteri uji bersifat intermediet terhadap antibiotik amoksisilin.
\end{abstract}

Kata Kunci :Amoksisilin, antibakteri, zona hambat

\begin{abstract}
Amoxicillin is an antibiotic that is often used in various treatments and effectively kills Gram positive and Gram negative bacteria. This study aimed to determine the antibacterial activity of amoxicillin against Gram positive bacteria (Bacillus subtilis, Staphylococcus aureus) and Gram negative bacteria (Escherichia coli, Pseudomonas aeruginosa). The research methods include making antibiotic concentrations (10 ppm, $15 \mathrm{ppm}, 20$ ppm, 25 ppm, 30 ppm); antibacterial testing using the paper disc method and measuring the inhibition zone formed. Data obtained that the average inhibition zone formed from the four bacteria is $0.03-0.44 \mathrm{~mm}$. At a concentration of $30 \mathrm{ppm}$, showed that the Staphylococcus aureus and Escherichia coli bacteria produced the widest inhibition zone of $0.38 \mathrm{~mm}$ and $0.44 \mathrm{~mm}$. It was concluded that the sensitivity of the four test bacteria was intermediate to the antibiotic amoxicillin.
\end{abstract}

Keywords :Amoxicillin, antibacterial, inhibitory zone

\section{PENDAHULUAN}

Mikroorganisme atau mikroba merupakan organisme yang ukurannya sangat kecil sehingga memerlukan mikroskop untuk mengamatinya. Oleh sebab itu, mikroorganisme disebut juga organisme mikroskopik. Mikroba hidup di hampir semua lingkungan (air, udara, tanah) maupun di benda mati serta mampu beradaptasi terhadap lingkungan yang ekstrim. Mikroorganisme yang berada di sekitar kita, ada yang bersifat menguntungkan maupun bersifat merugikan. Contoh mikroorganisme yang merugikan manusia (menyebabkan penyakit) adalah bakteri Bacillus subtilis, Staphylococcus aureus, Escherichia coli dan Pseudomonas aeruginosa [1].

Keempat bakteri tersebut merupakan sebagian kecil dari bakteri patogen yang dapat menyebabkan penyakit pada manusia, seperti infeksi saluran pernafasan (B. subtilis), infeksi penyakit kulit dan meningitis ( $S$. aureus), infeksi pencernaan $(E$. coli), infeksi pneumonia nosokomial ( $P$. aeruginosa) [2].
Salah satu pengobatan yang digunakan untuk mengobati penyakit infeksi yang disebabkan bakteri adalah dengan memberikan antibiotik. Antibiotik merupakan senyawa kimia yang dihasilkan oleh mikroorganisme (bakteri/jamur) dan memiliki sifat mampu menghambat pertumbuhan atau membunuh mikroorganisme [3]. Salah satu contoh obat antibiotik adalah amoksisilin.

Amoksisilin merupakan obat generik [3]dan termasuk golongan obat penisilin [4]. Amoksisilin merupakan antibiotik $\beta$-lactam yang berspektrum luas dan sering digunakan untuk mengobati berbagai penyakit infeksi yang disebabkan oleh bakteri Gram positif dan bakteri Gram negatif, seperti infeksi telinga, pneumonia, faringitis streptokokus, infeksi kulit, infeksi saluran kemih, infeksi Salmonella, infeksi Chlamydia dan penyakit Lyme [5].

Penelitian tentang uji antibakteri amoksisilin telah banyak dilakukan. Penelitian yang dilakukan sebelumnya menunjukkan bahwa amoksisilin pada konsentrasi 30 bpj mampu menghambat pertumbuhan Staphylococcus aureus 
sebesar $14 \mathrm{~mm}$ [6]. Amoksisilin 0,2 $\mu \mathrm{g} / \mathrm{ml}$ tidak memiliki efek antibakteri terhadap Salmonella typhi [7]. Hal ini didukung oleh penelitian yang dilakukan sebelumnya, dimana antibiotik amoksisilin pada konsentrasi $16 \mu \mathrm{g} / \mathrm{ml}$ mampu menghambat pertumbuhan $S$. aureus sebesar 9,67 $\mathrm{mm}$ [8].

Dari latar belakang tersebut, maka penelitian ini dilakukan untuk mengetahui perbedaan aktivitas antibakteri amoksisilin terhadap bakteri Gram positif (Bacillus subtilis, Staphylococcus aureus) dan bakteriGram negatif (Escherichia coli, Pseudomonas aeruginosa) dengan metode kertas cakram.

\section{METODE PENELITIAN}

Penelitian ini merupakan metode eksperimental dan dilakukan secara in vitro.

\section{Alat}

Alat-alat yang digunakan adalah cawan petri, mikropipet, beker glas, labu ukur, pengaduk, tabung reaksi, pipet, spatula, pinset, autoklaf, inkubator.

\section{Bahan}

Bahan yang digunakan dalam penelitian ini adalah antibiotik amoksisilin, bakteri Gram postif (Staphylococcus aureus, Bacillus subtilis), bakteri Gram negatif (Pseudomonas aeruginosa, Escherichia coli), akuades, kertas cakram, plastik wrap, aluminium foil, kapas lemak.

\section{Cara Kerja \\ Pembuatan Media Bakteri}

Media yang digunakan untuk uji aktivitas antibakteri adalah media Nutrient Agar (NA). Sebanyak 2 gram NA dilarutkan ke dalam Erlenmeyer yang berisi $100 \mathrm{ml}$ akuades, diaduk hingga larut dengan sempurna lalu dididihkan sampai berwarna seperti minyak goreng. Kemudian larutan NA disterilisasi dengan autoklaf pada suhu $121{ }^{\circ} \mathrm{C}$ selama 15 menit. Setelah disterilisasi, larutan NA dituang ke dalam cawan petri masing-masing sebanyak $15 \mathrm{ml}$. Ditunggu sampai mengeras dan diinkubasi selama 24 jam.

\section{Pembuatan Larutan Antibiotika Amoksisilin}

$50 \mathrm{mg}$ Amoksisilin digerus hingga halus lalu dilarutkan ke dalam $500 \mathrm{ml}$ akuades steril (didapatkan 1000 ppm). Dari larutan stok tersebut, kemudian dilakukan pengenceran sehingga didapatkan konsentrasi sebesar 10 ppm, 15 ppm, 20 ppm, 25 ppm dan 30 ppm. Untuk kontrol, digunakan akuades.

\section{Pembuatan Suspensi Bakteri Uji}

Bakteri uji diambil dari biakan murni menggunakan kawat ose, kemudian dimasukkan ke dalam tabung reaksi yang berisi $9 \mathrm{ml}$ Nutrient Broth
(NB). Lalu di-vortex hingga homogen. Diinkubasi pada suhu $37^{\circ} \mathrm{C}$ selama 24 jam.

\section{Uji Antibakteri}

Penanaman suspensi bakteri pada media Nutrient Agar (NA) dilakukan secara spread plate. Lalu diletakkan kertas cakram uji yang telah ditetesi antibiotik sesuai dengan konsentrasi yang telah ditentukan menggunakan mikropipet di atas media NA padat yang telah ditanam bakteri uji. Tiap tahap dilakukan secara aseptis. Lalu diinkubasi pada suhu $37^{\circ} \mathrm{C}$ selama 24 jam. Zona hambat yang terbentuk ditandai dengan adanya zona bening sekitar daerah kertas cakram. Zona hambat kemudian diukur menggunakan jangka sorong. Kepekaan bakteri terhadap antibiotik kemudian dilihat berdasarkan standar CLSI tahun 2016.

\section{HASIL DAN PEMBAHASAN}

Penelitian ini bertujuan untuk mengetahui sensitivitas atau resistansi suatu bakteri terhadap antibiotik Amoksisilin yang dilihat dari ada tidaknya zona hambat yang terbentuk menggunakan metode kertas cakram.

Zona hambat ditandai dengan adanya zona bening dan digunakan sebagai acuan penentuan tingkat resistensi bakteri terhadap antibiotik dimana semakin besar diameter zona bening yang terbentuk, maka semakin menghambat pertumbuhan bakteri. Terdapat 3 tingkat resistensi bakteri yaitu sensitif, intermediet dan resisten. Sensitif apabila terbentuk zona bening; resisten bila saat pengujian tidak terbentuk zona bening; dan dikatakan intermediet apabila terbentuk zona bening dengan diameter yang kecil [9].

Adapun standar zona hambat antibiotik Amoksisilin dapat dilihat pada Tabel 1. Tabel 2 menunjukkan bahwa keempat bakteri yang diujikan menghasilkan diameter zona hambat yang sangat kecil $(0,03-0,44 \mathrm{~mm})$ [9]. Adapun zona hambat antibiotik amoksisilin terhadap bakteri dapat dilihat pada Tabel 2.

Hal ini sesuai dengan penelitian sebelumnya yang menyatakan bahwa semakin besar konsentrasi uji maka zona hambat yang terbentuk juga semakin besar. Untuk bakteri Staphylococcus aureus dan Escherichia coli memiliki zona hambat yang terluas yaitu sebesar 0,38 mm dan 0,44 mm [10].

Amoksisilin termasuk antibiotik yang berspektrum luas dan bersifat bakterisidal (membunuh bakteri) pada bakteri Gram positif dan bakteri Gram negatif [3, 5]. Namun, berdasarkan standar zona hambat dari CLSI tersebut, maka bakteri Gram positif (Bacillus subtilis, Staphylococcus aureus) dan bakteri Gram negatif (Escherichia coli, Pesudomonas aeruginosa) menunjukkan tingkat intermediet terhadap antibiotik amoksisilin. Intermediet tidak dapat mengindikasikan 
bakteri tersebut bersifat resisten atau sensitif terhadap antibiotik. Dengan kata lain, pada penelitian ini antibiotik amoksisilin tidak berpengaruh terhadap keempat bakteri uji. Rendahnya zona bening yang terbentuk, kemungkinan diduga karena konsentrasi antibiotik yang digunakan (ppm) terlalu kecil.

Tabel 1. Hasil luas zona hambat Amoksisilin terhadap bakteri Gram positif dan negatif

\begin{tabular}{clccc}
\hline \multirow{2}{*}{ Agen antimikroba } & \multicolumn{1}{c}{ Bakteri } & \multicolumn{3}{c}{ Zona Hambat Antibiotik (mm) } \\
\cline { 2 - 5 } & $\begin{array}{l}\text { Enterobacteriaceae (Klebsiella } \\
\text { Amoksisilin }\end{array}$ & Sensitif & Intermediet & Resisten \\
\hline & $\begin{array}{l}\text { sp., Escherichia coli, Proteus } \\
\text { sp.) }\end{array}$ & $\leq 14$ & $14-16$ & $\geq 17$ \\
& $\begin{array}{l}\text { Pseudomonas aeruginosa } \\
\text { Staphylococcus aureus } \\
\text { Bacillus subtilis }\end{array}$ & $\leq 14$ & $15-16$ & $\geq 17$ \\
\hline
\end{tabular}

Tabel 2. Hasil luas zona hambat Amoksisilin terhadap bakteri Gram positif dan bakteri Gram negatif

\begin{tabular}{|c|}
\hline Bakteri \\
\hline Gram (+) \\
\hline Bacillus subtilis \\
\hline Staphylococcus aureus \\
\hline Gram (-) \\
\hline Escherichia coli \\
\hline Pseudomonas aeruginosa \\
\hline $\begin{array}{l}\text { Selain itu, kemungkinan disebabkan } \\
\text { amoksisilin tidak mampu menembus membran luar } \\
\text { dari masing-masing bakteri uji atau dikatakan } \\
\text { bakteri-bakteri tersebut telah resisten. Sebagai } \\
\text { pertahanan alamiah untuk bertahan hidup, bakteri } \\
\text { memiliki kekebalan alami berupa enzim yang dapat } \\
\text { merusak obat (misal: antibiotik) [11]. Enzim ini } \\
\text { dibentuk dari plasmid bakteri [12]. } \\
\text { Resistensi antibiotik disebabkan karena } \\
\text { penggunaan antibiotik yang tidak sesuai, dalam hal } \\
\text { ini amoksisilin yang digunakan tanpa resep atau } \\
\text { diresepkan tapi tidak sesuai dengan petunjuk dokter } \\
\text { [13]. Bakteri-bakteri patogen dalam tubuh menjadi } \\
\text { kebal terhadap satu atau beberapa jenis antibiotik } \\
\text { tertentu sehingga mengganggu proses pengobatan } \\
\text { [14]. }\end{array}$ \\
\hline
\end{tabular}

\section{KESIMPULAN}

Dari 4 bakteri yang diuji sensitivitasnya terhadap antibiotik amoksisilin, menunjukkan bahwa Staphylococcus aureus dan Escherichia coli memiliki zona hambat yang terluas yaitu sebesar $0,38 \mathrm{~mm}$ dan $0,44 \mathrm{~mm}$. Zona hambat antibiotik terhadap keempat bakteri menunjukkan intermediet (tidak dapat dipastikan sensitif atau resisten).

\section{DAFTAR PUSTAKA}

Zona Hambat yang terbentuk (mm)

$\begin{array}{llll}15 \mathrm{ppm} & 20 \mathrm{ppm} & 25 \mathrm{ppm} & 30 \mathrm{ppm}\end{array}$

-


J. Pijar MIPA, Vol.14 No.3, September 2019: 189-191

[9] Clinical And Laboratory Standards Institute (CLSI). 2016. Performance Standards For Antimicrobial Susceptibility. $26^{\text {th }}$ Edition. Vol 3. No 1. USA: Pennsylvania.

[10] Dwidjoseputro, D. 1994. Dasar-Dasar Mikrobiologi. Jakarta: Djambatan.

[11] Setiabudi. 1995. Pengantar Antimikroba. Jakarta: Gaya Baru.

[12] Jawetz, E., Melnick, J.L dan Adelberg, E.A. 2001. Mikrobiologi Kedokteran. Jakarta: Penerbit Salemba Medika.

[13] Laxminarayan R.D. \& Wattal, S. (2013). Antibiotic Ressistance-the need for global solution. Lancet Infect Dis. SS1473309913):70318-9.

[14] Utami, E.R. 2011. Antibiotika, Resistensi, Dan Rasionalitas Terapi. El-Hayah, 1(4). 191-198. 